Available online at GSC Online Press Directory

GSC Biological and Pharmaceutical Sciences

e-ISSN: 2581-3250, CODEN (USA): GBPSC2

Journal homepage: https://www.gsconlinepress.com/journals/gscbps

(RESEARCH ARTICLE)

\title{
Weed control in soybean (Glycine max (L.) Merrill) using acifluorfen and bentazon herbicides in North-central zone, Nigeria
}

\author{
Agahiu AE*
}

Department of Crop Production, Faculty of Agriculture, Kogi State University, Anyigba.

Publication history: Received on 11 May 2020; revised on 20 May 2020; accepted on 22 May 2020

Article DOI: https://doi.org/10.30574/gscbps.2020.11.2.0139

\begin{abstract}
The influence of acifluorfen and bentazon in the control of weeds in soybean was studied at the Students' Research and Demonstration Farm, Kogi State University, Anyigba during the 2016 growing season. A low shattering and early maturity soybean cultivar with high oil content, TGX 1830-20E was used in this trial. The two herbicides were applied post-emergence at two rates each. Acifluorfen (5-[2-chloro-4-(trifluoromethyl) phenoxy]-2-nitrobenzoic acid) was applied at 0.2 and $0.4 \mathrm{~kg}$ a.i/ha; bentazon (3-(1-methylethyl $(-(1 \mathrm{H})-2,1,3$-benzothiadazin $-4(3 \mathrm{H})-$ one $2,2-$ dioxide ) at 0.5 and $1.0 \mathrm{~kg}$ a.i $/ \mathrm{ha}$, while their mixtures, acifluorfen + asulam applied at 1.3 and $1.6 \mathrm{~kg}$ a.i $/ \mathrm{ha}$ and bentazon + asulam at 1.4 and $1.7 \mathrm{~kg}$ a.i/ha. Parameters measured included phytotoxicity of the herbicides to soybean, weed control effectiveness, plant height, number of pods/plant, number of seeds/plant, seed weight /plant and total grain yield (kg/ha). Results showed that weed control effectiveness was higher and the crop performance most especially in terms of total grain yield (Kg/ha) was better in plots that received mixture formulation of acifluorfen + asulam and bentazon + asulam than where acifluorfen or bentazon was applied as single formulation irrespective of rates. The highest grain yield (1066 kg/ha) obtained from plots to which $1.6 \mathrm{~kg}$ a.i/ha of acifluorfen + asulam was applied compared favourably with that realized from the hoe weeded plots (1044.5 kg a.i $/$ ha). Abysmally low grain yield was obtained from the weedy check.
\end{abstract}

Keywords: Phytotoxicity; Herbicide; Soybean; Weed; Acifluorfen; Bentazon; Grain yield

\section{Introduction}

Soybean (Glycine max (L.) Merrill) is an important grain legume and source of vegetable protein [1]. It is a major food grain legume and oil crop [2], and was domesticated in the $11^{\text {th }}$ century B.C. around northeast China and is believed to have been introduced to Africa in the $19^{\text {th }}$ century by Chinese traders along the east coast of Africa [3].

Soyabean is world's leading source of oil and protein. It has the highest protein content of all food crops and is second only to groundnut in terms of oil content among food legumes [4].

The spread of soybean from its native land of origin has been attributed mainly to its adaptability and predominant use as a food crop for human nutrition excellent protein supplement for enriching cereal diet, medicinal value and as an industrial crop [5]. Soybean oil can be utilized in cooking,treatment of diabetics and for the manufacture of tasty biscuit,soymilk salad,ice cream and margarine. Industrially, it is used in making soaps, inks, fertilizers, paints, vanishes, insecticides, adhesives, linoleum and lectin [6].

The United States of America is the largest producer of soybean. In Nigeria, it has been reported that farmers produce less than one tonne per hectare[7].

\footnotetext{
${ }^{*}$ Corresponding author: Agahiu AE
} 
Inspite of the numerous uses of soybean,its production is greatly hampered owing to intense weed interference. Weed infestation constitutes a major hindrance to the economic production of soybean in tropical region [8].

Weed control by the use of herbicides has become a common practice in many communities in Nigeria, owing to its obvious advantages. These include timely weed control especially in large farms at the critical period of weed interference, absence of root pruning as well as being more economical than mechanical and manual methods particularly where manual labourer costs higher among others. Reports of ineffectiveness of herbicides and/or phytotoxic effects on crops even at recommended rates are rife. In effect, there is the need for more appropriate information on the recommended herbicides. The present study was initiated to investigate the effectiveness of acifluorfen and bentazon herbicides and determine the rate that results in optimum soybean grain yields in the north central zone of Nigeria.

\section{Material and methods}

The trial was conducted in 2016 at the students' Research and demonstration Farm, Faculty of Agriculture, Kogi State University, Anyigba (Latitude $7^{\circ} 29^{\prime} \mathrm{N}$ and Longitude $7^{\circ} 11^{\prime} \mathrm{E}$ ) in the north-central zone of Nigeria. The experimental site was cleared of the initial vegetation, soil samples were taken from different locations, bulked and then sent to the laboratory of Department of soil and environmental management of Kogi State University for analysis. Results of soil test are presented in Table 1. The sampling of the weed flora of the experimental field was done using $1 \mathrm{~m}^{2}$ quadrat which was thrown randomly and the result presented in Table 2.

Table 1 Physico-chemical properties of the soil of the experimental site

\begin{tabular}{|c|c|}
\hline Properties & Value \\
\hline $\mathrm{pH}\left(\mathrm{H}_{2} \mathrm{O}\right)$ & 5.2 \\
\hline Total N ( $\left.\mathrm{g} \mathrm{kg}^{-1}\right)$ & 1.4 \\
\hline Organic C $\left(\mathrm{g} \mathrm{kg}^{-1}\right)$ & 15.2 \\
\hline Available $\mathrm{P}\left(\mathrm{mg} \mathrm{kg}^{-1}\right)$ & 4.0 \\
\hline Exchangeable $\mathrm{K}\left(\mathrm{c} \mathrm{mol} \mathrm{kg}{ }^{-1}\right)$ & 0.2 \\
\hline Exchangeable Ca (c mol kg-1) & 3.4 \\
\hline Exchangeable $\mathrm{Mg}\left(\mathrm{c} \mathrm{mol} \mathrm{kg}^{-1}\right)$ & 0.4 \\
\hline Exchangeable $\mathrm{Na}\left(\mathrm{c} \mathrm{mol} \mathrm{kg}^{-1}\right)$ & 0.4 \\
\hline Exchangeable acidity $\left(\mathrm{c} \mathrm{mol} \mathrm{kg}^{-1}\right)$ & 0.1 \\
\hline $\operatorname{ECEC}\left(\mathrm{c} \mathrm{mol} \mathrm{kg}{ }^{-1}\right)$ & 7.1 \\
\hline $\mathrm{Zn}\left(\mathrm{mg} \mathrm{kg}^{-1}\right)$ & 1.0 \\
\hline $\operatorname{Mn}\left(m g k^{-1}\right)$ & 30.3 \\
\hline $\mathrm{Cu}\left(\mathrm{mg} \mathrm{kg}^{-1}\right)$ & 4.0 \\
\hline $\mathrm{Fe}\left(\mathrm{mg} \mathrm{kg}^{-1}\right)$ & 7.8 \\
\hline Sand $\left(\mathrm{g} \mathrm{kg}^{-1}\right)$ & 740 \\
\hline Silt $\left(\mathrm{g} \mathrm{kg}^{-1}\right)$ & 125 \\
\hline Clay $\left(\mathrm{g} \mathrm{kg}^{-1}\right)$ & 135 \\
\hline
\end{tabular}

The experiment was set up using a randomized complete block design (RCBD) replicated three times. The experimental field was divided into three replicates after ploughing and harrowing. Each replicate was further divided into ten plots with each plot measuring $4 \mathrm{~m} \times 4 \mathrm{~m}\left(16 \mathrm{~m}^{2}\right)$.Soybean cultivar TGX 1830-20E obtained from Ministry of Agriculture Lokoja, Kogi state was sown two seeds per hole. The cultivar is low shattering and early maturing with high oil content [9]. On germination, the seedlings were thinned to one stand/hole two weeks after sowing(WAS).The planting spacing used was $5 \mathrm{~cm} \times 50 \mathrm{~cm}$ giving a total plant population of 400,000 plants/ha. Each weed control treatment was separated from 
the next by a spacing of $0.75 \mathrm{~cm}$ while an alley of $1.0 \mathrm{~m}$ separated each replicate. The post emergence application of herbicide was done four weeks after sowing by the use of a lever operated Knapsack sprayer. Phytotoxicity to soybean and weed control effectiveness of the herbicides were rated at 4,8 and 12 WAS. The criteria developed by [10] were used in rating the phytotoxicity to the crop on a scale of $0-10$, where 0 represents no injury and 10 represents dead plants. Weed control rating was virtually carried out using the rating scale of $0-10$ (where 0 represents no weed control or complete weed cover; 10 presents perfect weed control or no weed cover).

Data were collected on the following parameters; emergence and establishment counts, phytotoxicity to soybean and weed control effectiveness to the herbicides, plant height, number of pods per plant, number of seeds per plant, seed weight per plant and total grain yield, which was expressed in kilogram per hectare. The data obtained were subjected to the analysis of variance (ANOVA) and the treatment means compared using the Least Significant Different Test (LSD) (Steel and Torrie, 1980), where there were significant differences between treatment means.

Table 2 Initial weed species of the experimental site

\begin{tabular}{llll}
\hline Weed species & Family & Life form $^{\mathbf{1}}$ & Density $^{\mathbf{2}}$ \\
\hline Monech maciliatum & Acanthaceae & $\mathrm{A}$ & $\mathrm{XX}$ \\
Trianthema portulacastrum & Aizoaceae & $\mathrm{A}$ & $\mathrm{X}$ \\
Alternanthera pungens & Amaranthaceae & $\mathrm{P}$ & $\mathrm{X}$ \\
Andropogon gayanus & Poaceae & $\mathrm{P}$ & $\mathrm{XX}$ \\
Bracharia falcifera & Poaceae & $\mathrm{P}$ & $\mathrm{XXX}$ \\
Chloris pilosa & Poaceae & $\mathrm{X}$ & $\mathrm{XX}$ \\
Pennisetum pedicellatum & Poaceae & $\mathrm{A}$ & $\mathrm{XX}$ \\
Mitracarpus villosus & Rubiaceae & $\mathrm{A}$ & $\mathrm{XXX}$ \\
Sesamum alatum & Pedaliaceae & $\mathrm{A}$ & $\mathrm{XX}$ \\
Euphorbia hyssopifolia & Euphorbiaceae & $\mathrm{A}$ & $\mathrm{XX}$ \\
Ageratum conyzoides & Asteraceae & $\mathrm{A}$ & $\mathrm{X}$ \\
Echinochlo acolona & Poaceae & $\mathrm{P}$ & $\mathrm{X}$ \\
Paspalumcon jugatum & Poaceae & $\mathrm{P}$ & $\mathrm{XX}$ \\
Tridax procumbens & Asteraceae & $\mathrm{A}$ & $\mathrm{X}$ \\
Boehavia diffusa & Nyctaginaceae & $\mathrm{P}$ &
\end{tabular}

\section{Results}

The initial weed vegetation is shown in Table 2 . About $66 \%$ of the fallow weed population of the experimental field was annuals. As shown in Table 3, emergence and establishment counts were more impressive in plots that received the two rates each of acifluorfen and bentazon as well as $1.3 \mathrm{~kg}$ a.i/ha of acifluorfen plus asulam than in plots where mixtures of acifluorfen plus asulam and $1.4 \mathrm{~kg}$ a.i $/$ ha of bentzon plus asulam than in plots where mixtures of acifluorfen plus asulam at $1.6 \mathrm{~kg}$ a.i $/$ ha and bentazon plus asulam at $1.7 \mathrm{~kg}$ a.i $/$ ha were applied. Plants in the hoe weeded plots recorded the highest number of soybean seedlings and mature soybean plants in comparison to the other weed control treatments evaluated. 
Table 3 Effect of acifluorfen, bentazon and their mixtures with asulam on emergence and establishment counts of soybean in Anyigba

\begin{tabular}{lll}
\hline Weed control measures (kg a.i/ha) & Emergence count & Establishment count \\
\hline Acifluorfen,0.2 & 154 & 143 \\
Acifluorfen,0.4 & 156 & 145 \\
Bentazon,0.5 & 152 & 147 \\
Bentazon,1.0 & 150 & 144 \\
Acifluorfen+ Asulam,1.3 & 151 & 144 \\
Acifluorfen +Asulam,1.6 & 144 & 136 \\
Bentazon + Asulam,1.4 & 155 & 148 \\
Bentazon +Asulam,1.7 & 147 & 141 \\
Hoe weeding & 165 & 160 \\
Weedy check & 73 & 54 \\
LSD $(0.05)$ & NS & NS \\
\hline
\end{tabular}

Phytotoxic symptoms were not glaring in all the treatments except in plants in plots to which acifluorfen plus asulam at $1.6 \mathrm{~kg} \mathrm{a.i} / \mathrm{ha}$ and bentazon plus asulam at $1.7 \mathrm{~kg}$ a.i/ha were applied (Table 4). However, the symptoms observed in these plants gradually waned over time. Weed control effectiveness was better in plots to which the herbicides and their mixtures were applied than in plots treated with the two rates each of either acifluorfen or bentazon alone. Acifluorfen plus asulam at $1.6 \mathrm{~kg}$ a.i/ha and bentazon plus asulam at $1.7 \mathrm{~kg}$ a.i/ha achieved high level of weed control throughout the life cycle of the crop. And this was comparable to the hoe weeded plots. Weed control in the other treated plots was good and adequate up to 6 weeks after sowing (WAS) until a decline set in at the later stage of the plant growth and development except the acifluorfen applied singly at both rates. Weed control was indeed poor with the application of acifluorfen at 0.2 and $0.4 \mathrm{~kg}$ a.i $/ \mathrm{ha}$ (Table 4 ).

Table 4 Phytotoxicity and the effectiveness of weed control measures of the herbicides and their mixtures on soybean

\begin{tabular}{|c|c|c|c|c|c|c|c|c|c|}
\hline \multirow[t]{2}{*}{$\begin{array}{l}\text { Weed control measures } \\
\text { (kg a.i/ha) }\end{array}$} & \multicolumn{4}{|c|}{$\begin{array}{c}\text { Phytotoxicity }^{1} \\
\text { (weeks after sowing) }\end{array}$} & \multicolumn{5}{|c|}{$\begin{array}{l}\text { Weed control rating }{ }^{2} \\
(\%) \text { (Weeks after sowing) }\end{array}$} \\
\hline & 3 & 6 & 9 & 12 & 2 & 4 & 6 & 810 & 12 \\
\hline Acifluorfen, 0.2 & 1 & 1 & 0 & 0 & 43 & 41 & 39 & 3930 & 28 \\
\hline Acifluorfen, 0.4 & 2 & 1 & 1 & 0 & 46 & 43 & 43 & 4336 & 31 \\
\hline Bentazon, 0.5 & 2 & 2 & 1 & 1 & 52 & 50 & 50 & 4844 & 38 \\
\hline Bentazon,1.0 & 2 & 1 & 1 & 1 & 65 & 62 & 59 & 5656 & 50 \\
\hline Acifluorfen +Asulam, 1.3 & 2 & 2 & 1 & 1 & 82 & 80 & 77 & 7466 & 63 \\
\hline Acifluorfen + Asulam, 1.6 & 6 & 5 & 3 & 1 & 94 & 92 & 83 & 8175 & 68 \\
\hline Bentazon + Asulam, 1.4 & 3 & 2 & 1 & 1 & 82 & 78 & 74 & 7466 & 64 \\
\hline Bentazon +Asulam, 1.7 & 7 & 6 & 3 & 2 & 97 & 94 & 90 & 8680 & 72 \\
\hline Hoe weeding & 0 & 0 & 0 & 0 & 97 & 97 & 94 & 9092 & 93 \\
\hline Weedy check & 0 & 0 & 0 & 0 & 0 & 0 & 0 & $\begin{array}{lll}0 & 0 & 0\end{array}$ & 0 \\
\hline $\operatorname{LSD}(0.05)$ & 3.1 & 2.3 & 2.0 & 2.1 & 42 & 33 & 36 & 2925 & 21 \\
\hline
\end{tabular}


There was no significant effect of the weed control treatment on plant height. Plant height was almost the same irrespective of the weed control measure adopted except that recorded on the weedy plot (Table 5).Plants in the weedy plots were comparatively taller than those subjected to other weed control treatments. Pod yield was highest in plots treated with acifluorfen plus asulam at $1.6 \mathrm{~kg}$ a.i $/$ ha and bentazon plus asulam at $1.4 \mathrm{~kg}$ a.i $/ \mathrm{ha}$. And this as comparable to the pod yields realized from the hoe weeded plots and other plots to which mixtures of the herbicides were used. Generally, pod yield from the hoe weeded plots and mixtures of the herbicides were much higher than that obtained from plots in which single formulation of the herbicides was applied.The poorest pod yield (10 pods /plants) was recorded from the weedy plots. Among the herbicide treatments, acifluorfen plus asulam and bentazon plus asulam at both rates produced the highest number of seeds per plant which was comparable to the hoe weeded plots. But among the herbicide mixtures,seed yield per plant in plots treated with a mixture of bentazon plus asulam at $1.7 \mathrm{~kg}$ i/ha was slightly lower. The seed yield was 63 per plant.

Where acifluorfen or bentazon was applied singly, bentazon at $1.0 \mathrm{~kg}$ a.i/ha resulted in more seeds/plant than the other single formulations of the two herbicides. Seed production from plants in the unweeded (weedy) plots was the least. The seed weight per plant varied with the treatments applied.

The seed weight per plant obtained from the weedy plot was $0.4 \mathrm{~g}$ with the highest (20.8g) gotten from plants in plots treated with acifluorfen plus asulam at $1.6 \mathrm{~kg}$ a.i/ha. The trend in seed weight was at par with the seed yield/plant. Grain yields from plots treated with the herbicides and their mixtures with asulam were significantly $(\mathrm{P}<0.05)$ higher than that obtained from plots to which single formulation of either acifluorfen or bentazon was applied. The highest grain yields (kg/ha) were obtained from the hoe weeded plots, acifluorfen plus asulam at $1.6 \mathrm{~kg}$ a.i/ha,bentazon plus asulam at $1.4 \mathrm{Kg}$ a.i/ha and acifluorfen plus asulam at $1.3 \mathrm{~kg}$ a.i $/$ ha. The weedy check recorded the least grain yield of all the treatments applied.

Table 5 Effect of acifluorfen, bentazon and their mixtures with asulam on plant height, number of pods/plant, number of seeds/plant, weight of seeds/plant and grain yield

\begin{tabular}{llllll}
\hline $\begin{array}{l}\text { Weed control } \\
\text { measures (kg a.i/ha) }\end{array}$ & $\begin{array}{l}\text { Plant height } \\
\text { (cm) }\end{array}$ & $\begin{array}{l}\text { Number of } \\
\text { pods/plant }\end{array}$ & $\begin{array}{l}\text { Number of } \\
\text { seeds/plant }\end{array}$ & $\begin{array}{l}\text { Weight of } \\
\text { seeds/plant (g) }\end{array}$ & $\begin{array}{l}\text { Grain yield } \\
\text { (kg/ha) }\end{array}$ \\
\hline Acifluorfen,0.2 & 36 & 23 & 32 & 4.4 & 86.9 \\
Acifluorfen,0.4 & 34 & 23 & 38 & 5.8 & 104.1 \\
Bentazon,0.5 & 37 & 25 & 47 & 8.6 & 201.3 \\
Bentazon,1.0 & 36 & 27 & 53 & 9.2 & 293.1 \\
Acifluorfen +Asulam,1.3 & 36 & 41 & 70 & 15.2 & 602.7 \\
Acifluorfen+Asulam,1.6 & 38 & 47 & 82 & 20.8 & 1066.0 \\
Bentazon+Asulam,1.4 & 36 & 47 & 76 & 17.7 & 904.3 \\
Bentazon+Asulam,1.7 & 35 & 43 & 63 & 13.4 & 502.8 \\
Hoe weeding & 36 & 46 & 78 & 18.6 & 1044.5 \\
Weedy check & 40 & 10 & 12 & 0.4 & 5.8 \\
LSD(0.05) & NS & 17.4 & 23.4 & 12.1 & 65.3 \\
\hline
\end{tabular}

\section{Discussion}

The weed control effectiveness was higher in plots that received mixture formulation of acifluorfen plus asulam and bentazon plus asulam at all the rates examined than where acifluorfen or bentazon was applied as single formulation irrespective of the rates.

The weed control effectiveness in the hoe weeded plots was indeed comparable to that obtained from plots where the herbicides were applied in mixtures. This effectiveness of weed control could be linked to the mixture of acifluorfen and bentazon plus their mixtures with asulam which could have broadened the spectrum of weeds controlled since asulam is essentially a grass herbicide. And the weed of the experimental site was basically dominated by annual grass species. This corroborates the earlier work by [11] in which the mixture of imazaquin plus pendimethalin enhanced the 
spectrum of weed control. In the same vein,the weed control effectiveness of acifluorfen and bentazon and their selectivity to soybean could be attributed to the ability of the plant (soybean) to metabolise the toxic chemicals to nontoxic derivatives by the production of certain enzymes.

Soybean tolerance appears also to be due to rapid cleavage of the ether bond by homoglutathione producing the S-(3Carboxy-4-nitrophenyl) homoglutathione conjugate and 2-chloro-4-trifluoromehylphenol followed by other metabolism [12]. Susceptible weeds do not have the ability for this conversion and are therefore killed. The comparatively taller plants recorded in the plots left unweeded (weedy check) could be attributed to intense competition between the plant and weeds for the above ground resources leading to etiolation in the crop seedlings. This is in agreement with the reports of [13] who observed a similar trend in cowpea seedlings that were etiolated in plots in which the plants were left to grow with weeds unchecked. Pod yield, seeds per plant,seed weight and grain yield per hectare were more impressive and in fact, significantly higher in plants that received mixture formulations of the herbicides than those that were treated with single formulation of the herbicides. This could be linked to weed control effectiveness owing to the synergizing effects of the herbicides evaluated. Acifluorfen and bentazon are broadleaf herbicides while asulam is essentially grass herbicides and since the experimental field was dominated mostly by annual grass species, it was not surprising for the better weed control in plots that received the mixture of the herbicides. In consequence,the above and below ground resources were then maximally utilized by the plant leading to higher crop output as reflected in the results obtained most especially on the grain yield per hectare. This is similar to the findings of [14] who observed a trend of better weed control with the use of herbicide mixtures in contrast to single herbicide formulation especially in farms infested with both broad and narrow leaf weeds.

Significant reduction in grain yield was observed in plots treated with single formulation of acifluorfen and bentazon with more devastating results arising from the two rates of acifluorfen applied. This could probably be due to severe weed competition with the soybean plants owing to in effectiveness of the herbicides at those rates to contain the weed menace. This result confirms the observations of [15] who noted a considerable weediness in groundnut and soybean plots treated with lower rates of dual 500EC (metolachlor).

Grain yield was highest (1066 kg/ha) with the application of $1.6 \mathrm{~kg}$ a.i/ha of acifluorfen plus asulam which then decreased to $5.8 \mathrm{~kg} /$ ha when weeds were allowed to grow unchecked (weedy plots) throughout the life cycle of the crop resulting in yield reduction to about $98 \%$.

\section{Conclusion}

As evident from this study, the yield and yield components of soybean were higher with the mixture formulations of acifluorfen and bentazon each with asulam than their single formulations.It is therefore recommended that the mixture formulation of the herbicides most especially acifluorfen plus asulam at $1.6 \mathrm{~kg}$ a.i/ha be adopted as alternative to hoe weeding for impressive soybean grain production in the north-central zone of Nigeria.

\section{Compliance with ethical standards}

\section{Acknowledgments}

The author appreciates the support of the University for providingme land to carry out the trial, and to the individuals that assisted me in data collection and analysis, I remain eternally grateful to them all.

\section{Disclosure of conflict of interest}

This research article is completely without conflict of interest.

\section{References}

[1] Anon. (1994). Soybean Production and Utilization in Nigeria. Extention Bulletin No 68, NAERLS, Federal Ministry of Agriculture and Natural Resources, A.B.U., Zaria.

[2] Jullani AF. (2014). Effects of Plant Population of six soybean varieties grown under Irrigation and Rainfed conditions at Mopa, Nigeria. Research Synopsis, Department of Crop Production, K.S.U., Anyigba.

[3] Franc BS and Martins YS. (2010). Soybean Production in Nigeria: Problems and Prospect. Weed Research, $28,52$. 
[4] Olutayo MM. (2016). Response of soybean intercropping with maize (Zeamays ) in a Sub-humid Tropical Environment. Tropical Oil Journal, 11, 18-29.

[5] Owolabi MB Adegoke SW and Ajala F. (2011). A Comparative study of the Nutritional statusof children in villages in southern Nigeria using and not using soybeans. Food andNutrition Bulletin, 16, 48-64.

[6] Pandey BP. (2000). Soybean Response to Rotational Sequence, Row Spacing and Tillage system. Agronomy Journal, 95,81-104.

[7] Mofe ST. (2012). Influence of soybean (Glycine max (L.) Row Spacing on Velvet leaf interference. Weed Science, $32,112-140$.

[8] Madu BS. (2010).Weed Control in soybean (Glycine max (L.). Weed Science, 61, 15-26.

[9] Onyibe JE Kamara AY and Omoigui IO. (2006). Guide to soybean production in BornoState,Nigeria: Promoting sustainable Agriculture in Borno State (PROSAB). Ibadan, Nigeria, 17.

[10] Clay DV and Davison JG. (1978). An evaluation of sand culture technique for studying tolerance of fruit crop to soil- acting herbicides. Weed Research, Oxford, 18, 139-147.

[11] Adesina GO and Akinyemiju OA. (1998). Control of Weeds in Soybean with Imidazolinone herbicides. Nigerian Journal of Weed Science, 11, 7-15.

[12] Frear DS. (2010). Pesticide Biochemistry and Physiology, 23-56.

[13] Moody SKC. (2009). Effects of Weeds on yield and yield parameters of two grain legumes. Tropical Science Journal, 4 (2), 25-30.

[14] Maduka CT.(2001). Weeds and their control measures in Africa. In: Lank MB. International Symposium on weeds. CIMMYT, Nairobi, Kenya, 130-148.

[15] Oyinloye WS and Omotunde PS. (2008). Weed Control in major leguminous crops in Nigeria-A Review PAN, 20 (2), 50-61.

\section{How to cite this article}

Agahiu AE. (2020). Weed control in soybean (Glycine max (L.) Merrill) using acifluorfen and bentazon herbicides in north-central zone, Nigeria. GSC Biological and Pharmaceutical Sciences, 11(2), 226-232. 